\section{Fruit and vegetable intake by Brazilian adults, 2003}

\author{
Consumo de frutas e hortaliças \\ na população adulta brasileira, 2003
}

Patrícia Constante Jaime 1,2 Carlos Augusto Monteiro 1,2
1 Núcleo de Pesquisas Epidemiológicas em Nutrição e Saúde, Universidade de São Paulo, São Paulo, Brasil.

2 Faculdade de Saúde Pública, Universidade de São Paulo, São Paulo, Brasil.

Correspondence C. A. Monteiro Departamento de Nutrição, Faculdade de Saúde Pública, Universidade de São Paulo. Av. Dr. Arnaldo 715, São Paulo, SP 01246-904 Brasil. carlosam@usp.br

\section{Abstract}

This study estimated indicators of fruit and vegetable intake by Brazilian adults and examined the influence of demographic and socioeconomic variables on the consumption of these foods. We used the following indicators: daily fruit intake, daily vegetable intake, and daily consumption of five or more servings of fruits and vegetables per day. Only $41.0 \%$ of adults reported daily fruit intake, while $30.0 \%$ reported daily vegetable intake. Fruit and vegetable intake was more common in urban as compared to rural areas and increased in both genders with age, schooling, and number of household goods. We conclude that initiatives to promote fruit and vegetable consumption are necessary for the country as a whole, but special attention should be given to younger individuals, males, rural communities, and groups with less schooling and lower income.

Health Status; Food Habits; Diet Surveys

\section{Introduction}

According to estimates by the World Health Organization (WHO), inadequate consumption of fruits and vegetables is one of the five main factors in the global burden of disease 1. Fruits and vegetables are important foods in the composition of a healthy diet, since they have low energy density and are sources of micronutrients, fiber, and other components with functional properties 2. Epidemiological evidence shows an inverse association between consumption of these foods and the risk of cardiovascular diseases and some types of cancer 3,4.

Due to the global need to decrease the incidence of chronic, non-communicable diseases, in 2002 the WHO proposed a worldwide prevention strategy to promote healthy eating practices 5. One of the principal recommendations was increased consumption of fruits and vegetables, the reference for which was a recommended daily intake of $400 \mathrm{~g}$, or the equivalent of five servings of these foods 3 .

Little is known in Brazil about the frequency, distribution, and determinants of the population's consumption patterns for fruits and vegetables. The little available information comes from limited population-based studies or family budget surveys by the Instituto Brasileiro de Geografia e Estatística - IBGE (Brazilian Institute of Geography and Statistics), whose data only reveal the average availability of foods in 
the household and not the actual individual consumption. The first nationwide study to gather information on individual consumption of fruits and vegetables in Brazil was the World Health Survey (WHS), conducted in the country by the Fundação Oswaldo Cruz - FIOCRUZ (Oswaldo Cruz Foundation) in 20036 .

Based on the information gathered by the WHS, the current study estimated the frequency and distribution of fruit and vegetable intake and analyzed the influence of demographic and socioeconomic variables in determining consumption patterns for these foods by the adult population in Brazil.

\section{Methodology}

The WHS is a population survey conducted by the WHO to supply information on the health status of populations, as well as on the performance of the health systems in member countries. The WHS was conducted in Brazil from January to September 2003 under the responsibility of FIOCRUZ. Aimed at providing a representative national profile, the sample size was set at five thousand individuals 18 years of age or older. Sampling was conducted in two stages. The first was by census district with a probability proportional to size. Situation (urban or rural) and household size (number of members) stratified the primary selection units. Socioeconomic level, defined by mean income of heads of household in the district, was used for implicit stratification. In each household, selected randomly in the district, a resident was identified to answer the questions. Further details on the sampling procedures and other general aspects of the WHS are described elsewhere 6 .

Individual fruit intake was investigated by the WHS based on four questions: "In general how many times a week do you eat fruit?", "How many servings of fruit do you normally eat per day?", "In general, how many times a week do you eat vegetables (like lettuce, spinach, tomatoes, carrots, string beans, etc.)?", and “How many servings of vegetables or leafy vegetables do you normally eat per day?". The questions referring to the number of servings consumed were only asked for individuals who reported daily consumption of fruits or vegetables. Serving sizes were exemplified in the questionnaire.

Based on the questions furnished by the WHS, the following explanatory variables were created: daily fruit intake, daily vegetable intake, daily intake of fruits and vegetables, and adequate fruit and vegetable intake. Based on the WHO recommendations 3 , fruit and vegetable intake was considered adequate when consumption of these foods was daily and as long as their combined consumption reached five or more servings a day.

In the study of the distribution of indicators, we analyzed gender, age group (18-24, 25$39,40-54,55-64$, and $\geq 65$ years), level of schooling $(0-4,5-8,9-11$, and 12 or more complete years of study, with passing), urban or rural household situation, and a household assets score ( $0-3,4-7$, and 8 or more assets). To calculate this score, we considered the following: sound system, computer, refrigerator, dishwasher, clothes washer, microwave oven, cell phone, wire line phone, television, and automobile, ascribing one point to the presence of each of these assets. In the specific case of automobiles, two points were ascribed when there were two or more vehicles in the household.

Fruit and vegetable intake was described by relative frequency (\%), mean frequency, and confidence intervals, in an analysis stratified by gender. To analyze the independent effect of socioeconomic variables on adequacy of fruit and vegetable intake, we calculated the odds ratio according to quartiles for the variables schooling and household goods, adjusted by age group, gender, and urban or rural household situation and additionally for the alternative socioeconomic variable. Statistical analysis used the Epi Info (version 6.0) and SPSS (version 11) programs, using 5.0\% significance level and $95.0 \%$ confidence interval.

\section{Results}

According to the WHS, fewer than half $(41.0 \%)$ of adult individuals in Brazil consume vegetables daily, while fewer than a third $(30.0 \%)$ report daily consumption of fruits. Even fewer Brazilians (only one in five) report consuming fruits and vegetables every day, and only one in eight meets the recommendation of consuming five or more servings a day of these foods. Although the frequency of fruit and vegetable intake tends to be higher among women than men, in both genders the indicators show insufficient intake of these foods (Table 1).

Fruit and vegetable intake is greater in urban as opposed to rural areas and tends to increase with age, schooling, and household assets, both among women (Table 2) and men (Table 3 ). In both genders adequate fruit and vegetable intake (five or more servings a day) is twice as frequent in urban as compared to rural areas, twice as frequent among individuals with a 
Table 1

Indicators of fruit and vegetable intake by gender. Adult population, Brazil, 2003.

\begin{tabular}{|c|c|c|c|c|}
\hline \multirow{2}{*}{ Indicators } & \multicolumn{2}{|c|}{ Gender } & \multirow[b]{2}{*}{$\mathrm{P}$} & \multirow[t]{2}{*}{ Total $(n=5,000)$} \\
\hline & Female $(n=2,812)$ & Male $(n=2,188)$ & & \\
\hline \multicolumn{5}{|l|}{ Daily fruit intake: } \\
\hline Yes: \% $(95 \% \mathrm{Cl})$ & $34.1(32.0-36.6)$ & $25.5(24.1-27.0)$ & $p<0.001$ & $30.4(29.0-32.0)$ \\
\hline $\begin{array}{l}\text { Number of servings/day*: } \\
\text { mean }(95 \% \mathrm{Cl})\end{array}$ & $2.53(2.42-2.65)$ & $2.69(2.52-2.86)$ & & $2.59(2.50-2.67)$ \\
\hline \multicolumn{5}{|l|}{ Daily vegetable intake: } \\
\hline Yes: \% $(95 \% \mathrm{Cl})$ & $44.7(43.1-47.0)$ & $36.7(35.0-39.1)$ & $p<0.001$ & $41.2(40.0-43.0)$ \\
\hline $\begin{array}{l}\text { Number of servings/day*: } \\
\text { mean }(95 \% \mathrm{Cl})\end{array}$ & $2.53(2.39-2.67)$ & $2.78(2.59-2.97)$ & & $2.55(2.47-2.62)$ \\
\hline \multicolumn{5}{|c|}{ Daily intake of fruits and vegetables: } \\
\hline Yes: \% $(95 \% \mathrm{Cl})$ & $23.8(22.2-25.3)$ & $16.2(14.6-17.7)$ & $p<0.001$ & $20.4(19.3-21.6)$ \\
\hline $\begin{array}{l}\text { Number of servings/day: } \\
\text { mean }(95 \% \mathrm{Cl})\end{array}$ & $3.56(3.44-3.68)$ & $3.64(3.48-3.80)$ & & $3.59(3.49-3.69)$ \\
\hline \multicolumn{5}{|c|}{ Adequate fruit and vegetable intake ${ }^{\star \star}$ : } \\
\hline Yes: \% $(95 \% \mathrm{Cl})$ & $13.9(13.0-15.0)$ & $12.8(11.0-13.9)$ & $p=0.259$ & $13.5(13.0-14.0)$ \\
\hline
\end{tabular}

* Includes only those who reported daily consumption of the food.

** Daily consumption of five or more servings of fruits and vegetables.

Table 2

Association between fruit and vegetable intake and demographic and socioeconomic variables.

Female adult population, Brazil, 2003.

\begin{tabular}{|c|c|c|c|c|c|c|c|c|}
\hline \multirow{2}{*}{$\begin{array}{l}\text { Variables } \\
\text { Age (years }\end{array}$} & \multicolumn{2}{|c|}{ Daily fruit intake (\%) } & \multicolumn{2}{|c|}{ Daily vegetable intake (\%) } & \multicolumn{2}{|c|}{$\begin{array}{l}\text { Daily intake of fruits } \\
\text { and vegetables (\%) }\end{array}$} & \multicolumn{2}{|c|}{$\begin{array}{c}\text { Adequate fruit and } \\
\text { vegetable intake }{ }^{\star}(\%)\end{array}$} \\
\hline & & & & & & & & \\
\hline $18-24$ & 28.5 & $<0.001^{\star *}$ & 40.9 & 0.160 & 18.6 & $<0.001$ & 11.4 & $<0.001$ \\
\hline $25-34$ & 29.7 & & 48.5 & & 20.9 & & 12.8 & \\
\hline $35-44$ & 32.1 & & 43.9 & & 23.8 & & 13.0 & \\
\hline $45-54$ & 37.1 & & 44.5 & & 24.9 & & 12.4 & \\
\hline $55-64$ & 37.5 & & 43.6 & & 26.3 & & 18.2 & \\
\hline$\geq 65$ & 47.9 & & 51.5 & & 35.1 & & 20.6 & \\
\hline \multicolumn{9}{|c|}{ Schooling ( years) } \\
\hline $0-4$ & 25.7 & $<0.001$ & 35.8 & $<0.001$ & 17.1 & $<0.001$ & 10.6 & $<0.001$ \\
\hline $5-8$ & 31.7 & & 48.9 & & 24.1 & & 15.1 & \\
\hline $9-11$ & 39.9 & & 48.2 & & 25.7 & & 14.3 & \\
\hline$\geq 12$ & 53.3 & & 62.9 & & 39.9 & & 20.7 & \\
\hline \multicolumn{9}{|c|}{ Household situation } \\
\hline Urban & 35.8 & $<0.001$ & 47.6 & $<0.001$ & 25.3 & $<0.001$ & 14.9 & $<0.001$ \\
\hline Rural & 21.9 & & 30.2 & & 14.1 & & 7.6 & \\
\hline \multicolumn{9}{|c|}{ Household assets } \\
\hline $0-3$ & 20.2 & $<0.001$ & 27.6 & $<0.001$ & 10.4 & $<0.001$ & 6.6 & $<0.001$ \\
\hline $4-7$ & 35.5 & & 48.6 & & 25.6 & & 14.0 & \\
\hline 8 and + & 53.2 & & 59.3 & & 41.8 & & 26.7 & \\
\hline
\end{tabular}

* Daily consumption of five or more servings of fruits and vegetables.

** linear $\mathrm{p}$ trend, except for the variable household situation. 
Association between fruit and vegetable intake and demographic and socioeconomic variables.

Male adult population, Brazil, 2003.

\begin{tabular}{|c|c|c|c|c|c|c|c|c|}
\hline $\begin{array}{l}\text { Variables } \\
\text { Age (years }\end{array}$ & \multicolumn{2}{|c|}{ Daily fruit intake (\%) } & \multicolumn{2}{|c|}{ Daily vegetable intake (\%) } & \multicolumn{2}{|c|}{$\begin{array}{l}\text { Daily intake of fruits } \\
\text { and vegetables (\%) }\end{array}$} & \multicolumn{2}{|c|}{$\begin{array}{c}\text { Adequate fruit and } \\
\text { vegetable intake* (\%) }\end{array}$} \\
\hline $18-24$ & 25.4 & $<0.001^{\star *}$ & 32.8 & 0.004 & 12.7 & $<0.001$ & 11.9 & 0.040 \\
\hline $25-34$ & 19.2 & & 32.2 & & 11.7 & & 9.9 & \\
\hline $35-44$ & 24.4 & & 36.5 & & 16.4 & & 11.5 & \\
\hline $45-54$ & 27.0 & & 39.6 & & 18.1 & & 11.2 & \\
\hline $55-64$ & 30.2 & & 40.6 & & 23.7 & & 16.7 & \\
\hline$\geq 65$ & 33.1 & & 39.2 & & 21.5 & & 14.8 & \\
\hline \multicolumn{9}{|c|}{ Schooling (years) } \\
\hline $0-4$ & 20.2 & $<0.001$ & 28.5 & $<0.001$ & 12.0 & $<0.001$ & 8.0 & $<0.001$ \\
\hline $5-8$ & 23.9 & & 35.3 & & 12.5 & & 10.8 & \\
\hline $9-11$ & 27.5 & & 40.2 & & 18.2 & & 15.9 & \\
\hline$\geq 12$ & 40.7 & & 52.2 & & 30.7 & & 20.7 & \\
\hline \multicolumn{9}{|c|}{ Household situation } \\
\hline Urban & 27.6 & $<0.001$ & 37.9 & $<0.001$ & 17.7 & $<0.001$ & 13.2 & $<0.001$ \\
\hline Rural & 15.0 & & 26.5 & & 8.8 & & 6.4 & \\
\hline \multicolumn{9}{|c|}{ Household assets } \\
\hline $0-3$ & 17.1 & $<0.001$ & 25.7 & $<0.001$ & 9.4 & $<0.001$ & 5.8 & $<0.001$ \\
\hline $4-7$ & 25.2 & & 32.4 & & 14.9 & & 12.3 & \\
\hline 8 and + & 42.2 & & 49.1 & & 33.1 & & 22.4 & \\
\hline
\end{tabular}

* Consumption of five or more servings of fruits and vegetables.

** linear $\mathrm{p}$ trend, except for the variable household situation.

university education as compared to those with less than five years of schooling, and five times as frequent in households with eight or more assets as compared to those with fewer than four household assets. The increase in adequate fruit and vegetable intake is intense with age in the case of women and slight in the case of men.

Table 4 focuses on the association between socioeconomic variables and adequate fruit and vegetable intake. Essentially, schooling and the household assets score greatly and independently increase the frequency of adequate fruit and vegetable intake.

\section{Discussion}

Knowledge of the frequency and distribution of fruit and vegetable intake in the population, as well as their determinants, is necessary to orient national and local strategies to encourage consumption of these foods and promote healthy eating practices.
Our study showed that only a minority of individuals in the Brazilian adult population (some $13.0 \%$ ) follows the nutritional recommendations for fruit and vegetable intake, placing the country in an unfavorable situation, at least as compared to studies in developed countries $7,8,9,10$. The estimates in the current study are consistent with the results of the Brazilian National Household Budget Survey (Pesquisa de Orçamento Familiar) for 2002/2003, namely that the mean availability of fruits and vegetables in Brazilian households corresponds to approximately one-third of the recommendations for consumption of these foods 11 .

Our results point to differences in the patterns of fruit and vegetable intake in population subgroups based on gender and age and demographic and socioeconomic variables. Comparison of these findings with those of other studies on the determinants of fruit and vegetable intake is partially hindered because the published studies use a wide variety of methods to evaluate food consumption, in addition to presenting differences in the definition and cate- 
Crude and adjusted associations between adequate fruit and vegetable intake and quartiles

for schooling and household assets. Adult population, Brazil, 2003.

\begin{tabular}{|c|c|c|c|}
\hline \multirow[t]{2}{*}{ Variable } & \multicolumn{3}{|c|}{ Odds ratio for adequate fruit and vegetable intake } \\
\hline & Crude & Adjusted $1 *(95 \% \mathrm{Cl})$ & Adjusted $2^{\star \star}(95 \% \mathrm{Cl})$ \\
\hline \multicolumn{4}{|l|}{ Schooling } \\
\hline 1st quartile & 1.00 & 1.00 & 1.00 \\
\hline $2^{\text {nd }}$ quartile & 1.95 & $2.33(1.75-3.10)$ & $1.93(1.44-2.54)$ \\
\hline 3rd quartile & 2.30 & $3.32(2.47-4.45)$ & $2.47(1.81-3.35)$ \\
\hline $4^{\text {th }}$ quartile & 2.88 & $4.03(3.04-5.35)$ & $2.45(1.80-3.36)$ \\
\hline \multicolumn{4}{|c|}{ Household goods } \\
\hline 1st quartile & 1.00 & 1.00 & 1.00 \\
\hline $2^{\text {nd }}$ quartile & 1.89 & $1.77(1.31-2.41)$ & $1.59(1.17-2.16)$ \\
\hline 3rd quartile & 2.20 & $2.04(1.55-2.64)$ & $1.63(1.23-2.17)$ \\
\hline 4th quartile & 4.32 & $3.94(3.03-5.13)$ & $2.78(2.09-3.71)$ \\
\hline
\end{tabular}

* Odds ratio adjusted by age, gender, and household situation.

** Odds ratio adjusted by schooling or household assets, age, gender, and household situation.

gorization of fruits and vegetables. At any rate, as we will see, the results of our study are generally consistent with those in the literature.

We observed that men and younger individuals consumed less fruit and vegetables. Studies in other countries have also shown that women tend to consume more fruit and vegetables than men 7,12,13. The same has been observed in relation to age: estimated fruit and vegetable intake in 14 geographic regions, including Africa, the Americas, Europe, and Asia, was greater in older than in younger individuals 4 . In Brazil, a household survey on risk factors and morbidity related to non-communicable diseases in 15 State capitals and the Federal District (Brasília) during the same period as the WHS also showed an upward trend in the consumption of fruits and vegetables according to age 14 . This positive association between age and fruit and vegetable intake can be interpreted as a cohort effect, since older individuals formed their eating habits during a period in which the "modern" eating pattern, known for its high level of overall fat, saturated fats, sugar, and salt and the lack of complex carbohydrates, fiber, and micronutrients was still less pronounced in the country.

The two socioeconomic indicators we used (schooling and the household assets score) were positively associated with fruit and vegetable intake, thus reproducing findings from other studies $8,9,13,15$. In the specific case of our study, schooling and household goods independently increased the odds of adequate fruit and vegetable intake, indicating that both individual access to information and family purchasing power are relevant for determining the consumption of these foods. Thus, actions that expand the population's access to correct information on the importance of consuming fruits and vegetables for health may be as important as actions leading to price reduction for these foods.

We also observed that although fruit and vegetable intake is insufficient in Brazil, it has tended to be higher in urban areas, with twice the proportion of individuals reporting adequate consumption of these foods in cities as compared to the countryside. This finding is entirely consistent with the household availability of fruits and vegetables in Brazil, which is twice as high in urban as compared to rural areas 11 .

Based on the results, we conclude that initiatives to promote consumption of fruits and vegetables in Brazil should cover the country's population as a whole, given that overall consumption falls short of the current recommendations. However, special attention should be given to young individuals, males, rural areas, and social strata with limited schooling and low income. 
Resumo

O presente estudo estimou a freqüência e a distribuição do consumo de frutas e hortaliças e analisou a influência de variáveis demográficas e sócio-econômicas na determinação do padrão de consumo desses alimentos na população adulta do Brasil. Os indicadores do consumo alimentar foram: consumo diário de frutas, de hortaliças, consumo diário de frutas e hortaliças e consumo diário de cinco ou mais porções de frutas e hortaliças. Menos da metade (41,0\%) dos indivíduos adultos refere o consumo diário de frutas enquanto menos de um terço (30,0\%) refere o consumo diário de hortaliças. O consumo de frutas e hortaliças

\section{Contributors}

P. C. Jaime and C. A. Monteiro participated jointly in designing the article, analyzing the data, and drafting and reviewing the manuscript.

\section{References}

1. World Health Organization. The world report 2002: reducing risks, promoting healthy life. Geneva: World Health Organization; 2002.

2. Van Duyn MAS, Pivonka E. Overview of the health benefits of fruit and vegetable consumption for the dietetics professional: selected literature. J Am Diet Assoc 2000; 100:1511-21.

3. World Health Organization. Diet, nutrition and the prevention of chronic diseases. Report of a Joint WHO/FAO Expert Consultation. Geneva: World Health Organization; 2003. (WHO Technical Report Series 916).

4. Lock K, Pomerleau J, Causer L, Altmann DR, McKee M. The global burden of disease attributable to low consumption of fruit and vegetables: implications for the global strategy on diet. Bull World Health Organ 2005; 85:100-8.

5. World Health Organization. WHO global strategy on diet, physical activity and health. Food Nutr Bull 2004; 25:292-302.

6. Szwarcwald CL, Viacava F, Vasconcellos MTL, Leal MC, Azevedo LO, Queiroz RSB, et al. O Brasil em números. Radis 2004; 23:14-33.

7. Thompson B, Demark-Wahnefried W, Taylor G, McClelland JW, Stables G, Havas S, et al. Baseline fruit and vegetable intake among adults in seven 5 a day study centers located in diverse geographic areas. J Am Diet Assoc 1999; 99:1241-8.

8. Roos G, Johansson L, Kasmel A, Klumbiené J, Prättälä R. Disparities in vegetables and fruit consumption: European cases from the north to the south. Public Health Nutr 2001; 4:35-43.

9. Giskes K, Turrell G, Patterson C, Newman B. Socio-economic differences in fruit and vegetable consumption among Australian adolescents and adults. Public Health Nutr 2002; 5:663-9. é maior nas áreas urbanas do que nas áreas ruraise aumenta com a idade e escolaridade dos indivíduos, $e$ com o número de bens no domicílio, em ambos os sexos. Concluímos que iniciativas de promoção do consumo de frutas e hortaliças devem atender a população como um todo, mas que especial atenção deve ser dada a indivíduos jovens, ao sexo masculino, a áreas rurais e aos estratos populacionais com insuficiente escolaridade e baixa renda.

Nível de Saúde; Hábitos Alimentares; Inquéritos Sobre Dietas
10. O’Brien M, Kiely M, Galvin M, Flynn A. The importance of composite foods for estimates of vegetable and fruit intakes. Public Health Nutr 2003; 6:711-26.

11. Instituto Brasileiro de Geografia e Estatística. Pesquisa de orçamentos familiares 2002-2003: análise da disponibilidade domiciliar de alimentos e do estado nutricional no Brasil. Rio de Janeiro: Instituto Brasileiro de Geografia e Estatística; 2004.

12. Baker AH, Wardle J. Sex differences in fruit and vegetable intake in older adults. Appetite 2003; 40:269-75.

13. Subar AF, Heimendinger J, Patterson BH, KrebsSmith SM, Pivonka E, Kessler R. Fruit and vegetable intake in the United States: the baseline survey of the Five a Day for Better Health Program. Am J Health Promot 1995; 9:352-60.

14. Secretaria de Vigilância em Saúde, Ministério da Saúde/Secretaria de Atenção à Saúde, Ministério da Saúde/Instituto Nacional de Câncer. Inquérito domiciliar sobre comportamento de risco e morbidade referida de doenças e agravos não transmissíveis: Brasil, 15 capitais e Distrito Federal, 2002-2003. Rio de Janeiro: Instituto Nacional de Câncer; 2004

15. Anderson JV, Bybee DI, Brown RM, McLean DF, Garcia EM, Breer ML, et al. 5 a day fruit and vegetable intervention improves consumption in a low income population. J Am Diet Assoc 2001; 101:195-202.

Submitted on 04/May/2005

Final version resubmitted on 31/Aug/2005

Approved on 26/Sep/2005 